divisions of the Siwaliks and the underlying Nari beds, and assigns ages in terms of European nomenclature ranging from Aquitanian to Pliocene. Fifty of these species are of his own discovery. In a later paper, "Correlation of the Siwaliks with Mammal Horizons of Europe" (Rec. Geol. Surv. India, 43 ; 1913), he succeeds in splitting up the Tertiary freshwater strata of India and Burma into no less than thirteen horizons with their characteristic fossils, ranging from the Gaj below to the Boulder Conglomerate at the top of the Siwaliks. He shows the European equivalent of each horizon, and also the equivalence of the freshwater strata with the marine Tertiary beds of India. His correlation has been of immense use to all later workers on the Tertiaries of India.

Pilgrim also made an expedition to Bhutan, and wrote a joint memoir, with Mr. W. D. West, on the geology of a portion of the Simla Hills.

With the help of the late Mr. Vinayak Rao, Pilgrim added largely to the already large collections of Siwalik vertebrate fossils in the Geological Museum in Calcutta, and he thus had at his disposal an immense mass of material, partly already described in the past by Lydekker and partly new. To this material Pilgrim devoted all available time while in the Indian service, work that he continued in London at the Natural History Museum after his retirement. The total result is an impressive mass of fine memoirs in the Palaeontologica Indica descriptive of various groups of Indian vertebrates, of which one may list in chronological order the Giraffidæ of India (1911), the Vertebrata of the Gaj of the Bugti Hills and the Punjab (1912), the Perissodactyla of the Burma Eocene (1925), the Suidre of India (1926), the Artiodactyla of Burma (1928), the Carnivora of India (1932), and finally the Bovidæ of India (1939). Separate mention may be made of Pilgrim's discoveries of fossil primates in the Siwaliks, comprising no less than five new species and two new genera. In his view Sivapithecus, one of these latter, was, when he wrote (1915), the closest anthropoid phylogenetically to man, with the possible exception of Pithecanthropus and Eoanthropus.

The preparation of this note has been a sad task for me, for Pilgrim, the late James Malcolm Maclaren and I travelled out to Calcutta together in 1902, on the $\mathrm{P}$. and $\mathrm{O}$. Coromandel, to join the Geological Survey of India.

L. L. Fermor.

\section{Prof. H. G. Denham}

THE death, which occurred on February 15, 1943, of Prof. Henry George Donham, professor of chemistry in, and rector of, Canterbury University College, Christchurch, New Zealand, and chairman of the New Zealand Council of Scientific and Industrial Research, has deprived the University of New Zealand of a distinguished teacher, administrator and investigator, and both the Dominion and the British Empire of a man who had done eminent public service in vigorously fostering the advancement of pure and applied science in his native country.

He was born in Christchurch on July 14, 1880, and received his early education at Sydenham School, whence he proceeded with a scholarship to the Boys' High School. Having completed his school education, he adopted school teaching as a profession, but while still engaged on this work entered Canterbury College as a student in 1901. Here he decided to study chemistry as his main subject when Dr. W. P. Evans was appointed to the chair of chemistry in 1903 .
He won the Chemistry Exhibition and graduated B.A. in 1904 and M.A. with first-class honours in chemistry in 1905. Having earried out an investigation on the temperature of combustion of methane in the presence of palladiumized asbestos, he obtained the M.Sc. degree and won the 1851 Exhibition Science Research Scholarship in 1906. In the same year I had the good fortune to welcome him as a research student in the Muspratt Laboratory of Physical and Electro-Chemistry, University of Liverpool. Denham's cheery and good-natured personality and his keenness and enthusiasm for research in physical chemistry were a great source of strength to the newly opened laboratory, whither a few years later were to come three other very able young New Zealand investigators-Prideaux, Farrow and Stubbs.

Denham proved to be an exceptionally gifted research student. His first work was the determination of the degrees of hydrolysis of salts in aqueous solution by means of the hydrogen electrode. This novel and pioneering piece of electrometric research led Denham on to two other very interesting lines of investigation. Having found that in the presence of the hydrogen electrode anomalous values for the hydrogen ion concentration in solutions of lead salts were obtained-results which could be explained only by the assumption of a partial reduction of bivalent to univalent lead ions at the surface of the platinumhydrogen electrode he joined forces with A. J. Allmand, then a research student in my laboratory. By means of an automatic thermo-circulation apparatus they caused a solution, say, of lead acetate, to pass constantly upwards through a hot steamjacketed column containing metallic lead and then downwards through a cooled column (of the same solution). In this way they found that metallic lead crystallized out from the solution in the cooler part, a result which could be best explained by the reversible equilibrium

$$
\mathrm{Pb}+++\mathrm{Pb} \underset{\text { cooling }}{\stackrel{\text { hearing }}{\rightleftarrows}} 2 \mathrm{~Pb}+,
$$

similar to that which occurs in the case of copper and gold salts. Encouraged by this remarkable result, Denham then went on alone to apply the same method to other salts and demonstrated the existence in aqueous solution of a univalent cadmium ion, a 'subvalent' thallium ion $\left(\mathrm{Tl}_{2}+\right)$ and a bivalent bismuth ion. In the electrometric investigation of the hydrolysis of salts of zinc, magnesium, thorium, cerium, nickel and cobalt, Denham found that very irregular and fluctuating results were obtained. These he explained by the assumption of the existence of a microheterogeneous system, that is, the presence of colloidally dispersed hydroxides or basic salts in the solution. A closer examination of these 'anomalies' led to the publication of an interesting paper. In connexion with this work it may be mentioned that Kolthoff and Kameda in 1928 explained the anomalous results as due to the adsorption of metal cations on the platinum black. The equivalent amount of hydrogen ions liberated in the solution upsets the hydrolysis measurement. The work on the hydrolysis of salts was completed by an electrometric determination (with the hydrogen electrode) of the degrees of hydrolysis in aqueous solution of the blue and green chromic sulphates.

Denham's last piece of work in my laboratory dealt with the formation of 'autocomplexes' (anionic complexes) in solutions of cupric chloride, cupric bromide 
and cobalt bromide, in which an ionic transport method was employed. For his excellent research work he was awarded the D.Sc. degree by the University of Liverpool. Denham then went to continue his researches in Germany, and having arrived in the laboratory of Prof. Bredig at the University of Heidelberg he informed. Bredig that he wished to work for the Ph.D. degree of that University but could only spend about a year on the job. Prof. Bredig was astonished, said that such a thing was very difficult if not impossible-but he could have a shot at it if he wished! Little did he realize Denham's tremendous powers of concentration and hard work, not to mention his great insight and skill as an investigator. The result was Denham did so well that he got his Heidelberg Ph.D. in the year. His subject of investigation was a quantitative study of the reversible catalytic reduction of titanic salts by hydrogen gas (in presence of platinum black). It formed one of Bredig's great series of studies in heterogeneous catalysis.

With a record of six published papers and the research degrees of two European universities (a pretty good record for $3 \frac{1}{2}$ years work), Denham returned to New Zealand in 1910 and acted for a time as research student and honorary lecturer at Canterbury College. Then in 1912 he obtained a post as lecturer in chemistry under Prof. B. D. Steele at Brisbane (University of Queensland), where he was appointed head of the Chemistry Department and acting-professor during the absence of Prof. Steele on war-work in England, obtaining the title of assistant-professor at the end of the War.

In 1921 Denham published his useful text-book of inorganic chemistry, and in the same year was appointed professor of inorganic chemistry at the University of Cape Town, remaining there only two years, for in 1923 he was offered and accepted the succession to the chair of chemistry at Canterbury College, Christchurch-a post which he still occupied at the time of his death. From 1941 he held also the high office of rector of the College. During his twenty years as professor, Denham proved himself to be a very active and excellent university teacher and administrator, the much-loved father of his students, and a wise, energetic and forward-looking member of the academic body. $\mathrm{He}$ was a member of the Academic Board of the University from its inception in 1927, and a representative of that Board on the University Senate from 1935. Apart from his great work in University and College affairs, Denham was very active in fostering and promoting the advancement and application of science in New Zealand. He was a fellow of the Royal Institute of Chemistry of Great Britain and Ireland, an original fellow of both the Australian Chemical Institute and the New Zenland Institute of Chemistry, and a fellow of the Royal Society of Now Zealand and of the New Zealand and Australian Association for the Advancement of Science. Of the latter body he was president of Section B (Chemistry) for the Hobart meeting in 1928, and Liversidge Lecturer for the Canberra meeting in 1939 .

Denham took a very active and important part in the promotion and development of scientific control and research in connexion with both primary and secondary industries in New Zealand. Thus he was a member of the New Zealand Council of Scientific and Industrial Research from its establishment in 1926, becorning chairman in 1934. He was active in the foundation of the Wheat Research Institute in 1927 and chairman of its committee from the start. Denham's interest in the successful promotion of agricultural science and practice can be realized when it is stated that he was a member of the Board of Governors of Canterbury Agricultural College during 1928-41 and its chairman during 1932-38; a member of Council of the New Zealand School of Agriculture from its foundation in 1937 until 1941, and a member of the committees of the Dairy Research Institute and the Wool Manufacturers' Association.

During his stay in Brisbane and Cape Town, Denham published a number of papers on complexes in solutions of copper and cobalt salts and on the existence and preparation of the suboxides and subsalts of lead, cadmium and bismuth. Some doubt has been cast on the existence of certain of these suboxides and subhalides by the later work of Hollens and Spencer (1934), using magnetic susceptibility measurements, and by that of Hedger and Terrey (1936) using X-ray methods. Some of the substances in question were prepared by methods which Denham's work had also shown to be doubtful.

During his busy years as professor at Christchurch, Denham never lost his interest in research, and in collaboration with senior students published a number of papers on salt hydrolysis and on the ternary systems zine oxide - nitric acid - water and lead oxide - nitrogen pentoxide - water.

The coming of the War brought new and heavy burdens. He threw himself fully into the great war effort of New Zealand, but there seems little doubt that this extra strain was too much for a man who had never spared himself in his devoted services to his students, the University, the community and science. Fortunately, he lived Iong enough to know of the great honour that was coming to him, namely, honorary membership of the Society of Chemical Industry.

As one of his old teachers, I have always had the highest regard and affection for him, and count it a special piece of good fortune for myself that I was able to help him at an early stage in his career. $\mathrm{He}$ was a great son of his native land, and a very fine example of a man who devoted himself wholeheartedly not enly to the advancement of science and sound learning but also to the promotion of the health, happiness and prosperity of his fellow countrymen by the means which science can provide.

\section{F. G. Donnan.}

\section{Sir Michael Sadler, K.C.S.I., C.B.}

The death of Sir Michael Sadler removes from the world of education an elder statesman universally honoured for his achievement and almost as widely trusted for his wisdom. He was never, as too many of our educationists are apt to be, merely the brilliant amateur in the ficld, or the politician in disguise. Both these parts he could have played to perfection, if he had so chosen, for he had the gift of persuasive eloquence and great personal charm. At Oxford he became president of the Union in his second year, but made no mistake about his first classes in the Schools. Then in 1895 he settled down to the Oxford University Extension work, shaping in a very short time the main lines which it has since followed. He passed on almost at once to spend eight years as director of special inquiries and reports at the Board of Fducation, and used the opportunity to conduct a thorough study of what was being done outside Great Britain, particularly in Prussia and generally 